\title{
Australia urged to revise Antarctic efforts
}

[SYDNEY] The first comprehensive review of Australia's research in Antarctica in the 50 years since a permanent national programme was established has recommended sweeping changes. The aim is to divert funds to support more science if savings can be made in infrastructure costs.

The report, released last week by the Antarctic Science Advisory Committee after an exhaustive analysis of possible changes and uncertainties 30 years ahead, is "a trailblazer" in the history of Antarctica, says the committee chair, Michael Stoddart, deputy vice-chancellor at the University of New England in Armidale, New South Wales.

Stoddart, a zoologist, points to a shift in government policy for Antarctica. Unlike all other areas of publicly supported research, he says, the direction of Australian science in Antarctica "is entirely in support of government policy positions". In its brief to the review, the government advanced its policy from "maintaining" the nation's interests in Antarctica to "enhancing" them.

In the complex territorial and, increasingly, commercial affairs of Antarctica, the review says that more science is central to "projecting an image of involvement with its Antarctic Territory" and supporting Australia's goal of exerting greater influence among the countries of the Antarctic Treaty System. Australia is bidding to have an office for the treaty established in Hobart, Tasmania, but agreement has yet to be reached on whether there should be such an office, let alone its location - Argentina also wants it.

Australia's work at four permanent bases and two part-time stations on the Antarctic continent and sub-Antarctic islands has become constrained by dependence on the transport of personnel, equipment and supplies solely by ice-breaking ship in summer months. Demands for more fishing and tourism, changes to sovereignty over land and sea, and international collaboration have become major factors determining how research can be developed while government finance continues to be limited.

The review says savings could result from concentrating effort at Davis, one of Australia's three permanent bases on the continent, and converting Mawson and Casey bases to unstaffed, automated operation in winter months once technology makes this possible. Leasing or sharing one or two bases with other countries are also options.

As well as studying scientific, international and commercial interests and logistics, the committee commissioned a panel to study the intrinsic value of Antarctica. The main scientific goal identified by the committee is boosting the base of knowledge about Antarctic weather systems. Rex Moncur, director of Australia's Antarctic Division, agrees that information about the Antarctic region is "the weak link" in current models of global change.

Australia spends \$A60 million a year (US\$42 million) on the Antarctic Division, which employs about 120 scientists and 185 support staff full-time. The division supports a larger number of researchers from universities and research agencies for short periods of work in Antarctica.

Australia's year-round research and weather monitoring have to be serviced by the leased ice-breaker, Aurora Australis, which takes a month for a round trip. Eighty per cent of the division's budget is required for infrastructure, with about \$A20 million consumed by the ship charter and by helicopter operation close to the bases.

As the present supply ship can provide only 60 days of science at sea, the report advocates chartering a smaller research vessel for dedicated surveys of the Southern Ocean. The committee also highlights the need for greater flexibility. Australia is now

\section{'Disappointing lack of action' over illegal fishing}

[SYDNEY] Sensitivities about exploiting Antarctica's resources surfaced at the meeting in Hobart, Tasmania, last week of the Commission for the Conservation of Antarctic Marine Living Resources (CCAMLR). This followed revelations of illegal fishing, mostly unreported, in the Southern Ocean. Rex Moncur, director of the Antarctic Division, estimates the poaching is worth $A \$ 500$ million (US $\$ 350$ million).

After Australian fishermen and scientists expressed alarm at the rapid depletion of some species, notably the Patagonian toothfish, the Australian Navy apprehended foreign vessels alleged to be operating illegally in the zone around the Heard and Macdonald Islands.

The two ministers in the Australian government concerned with Antarctica and resources expressed disappointment that "more concrete action could not be agreed" by CCAMLR after
Australia pressed for other countries to follow its example of scientific observers on vessels to monitor catches and report vessels seen poaching.

But CCAMLR, which operates by consensus and has no direct powers to police its decisions, agreed only to prohibit fishing for toothfish in three areas for which conservation measures are not in place, and to "tougher" controls on port access.

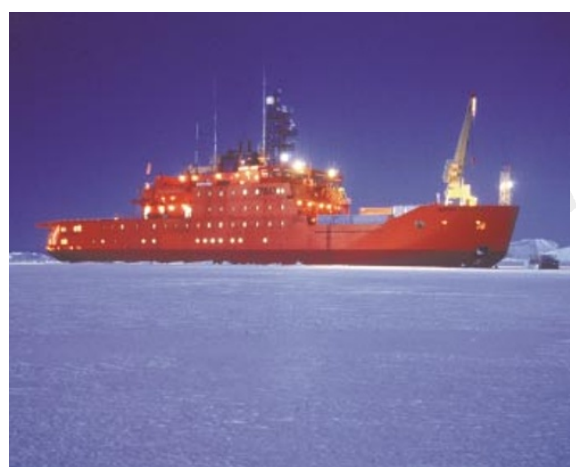

Time for retirement? Dependence on the Aurora Australis icebreaker is constraining research.

virtually alone among Antarctic countries in its total dependence on sea transport.

Building a full-sized airstrip at one base for intercontinental flights and small landing strips for light aircraft at other bases would allow scientists and equipment to be flown from Australia and around the territory for short periods of field work. Stoddart says: "We need to get researchers to where the science needs to be done, rather than around where the bases are placed."

The committee had no brief to cost options for ski-equipped aircraft able to use ice runways and conventional aircraft needing gravel runways. But Moncur says they range from \$A5 million to \$A15 million.

Building facilities for air transport would have environmental effects certain to stir activists campaigning to preserve Antarctica as wilderness. Moncur, whose division manages Australia's Antarctic territories and bases as well as the research, considers that there are incentives to share resources with countries keen to be involved in Antarctica, especially some of Australia's Asian neighbours.

Following the aim of researching global change, the committee gives priority to studies of the Southern Ocean and on the high plateau of the continent, where Australian astronomers are site-testing with Americans for a possible infrared telescope (see Nature 385,194 ; 1997), environmental protection, meteorology, fisheries and tourism.

Any extension of tourism from the short ship-based visits of today to catering, for example, to "adventurers" would require at least a summer base to be available. The report concludes tourism would "best be undertaken away from research sites" and would need to stand alone and have significant capacity for search and rescue.

Ian Macdonald, parliamentary secretary responsible for Antarctic matters, welcomed the report. Rapid decisions are expected in time for implementation in the May 1998 budget, the last before Australia's election. The report is accessible on the Internet at www.antdiv.gov.au/foresight. 